\title{
1. A global political economy
}

Economics is about production, consumption, distribution and exchange. Alfred Marshall says it is about ordinary people in 'the ordinary business of life' (1949 [1890]: 1). By the ordinary business of life he means the ordinary life of business.

The life of business is the life of negotiation. It is the life of bargained consent. Adam Smith, who regarded the unique individual as the sole judge of sensation, argued that unimpeded exchange is in itself the moral sentiments put on public display: 'Give me that which I want, and you shall have this which you want, is the meaning of every such offer' (Smith, 1961 [1776]: I, 18). The life of business is the tolerant respect for persons precisely because it devolves the what, the how much and the for whom to the sovereign monad who alone can know if and where the shoe is pinching. Economics is buying and selling, supply and demand, allocative efficiency and the whirlwind of surprise. Without economics we would surely starve.

Politics is about 'man's control over the minds and actions of other men' (Morgenthau, 2006 [1948]: 16). It is about top-down order, acknowledged leadership and an up-and-doing state that coordinates, commands and compels. Dictatorship or democracy, politics is about the collective redistribution of rights and claims that determine 'who gets what, when, and how': 'The study of politics is the study of influence and the influential' (Lasswell, 1958 [1936]: 13).

Politics is not about decentralised price-setting as if guided by an invisible hand. Instead it is about dominance and directive. Iron hand or velvet glove, politics is the legitimacy of the barracks when the alternative to the Leviathan is the war of all against each: 'In the final analysis, force is the ultimate form of power' (Gilpin, 1975: 24). Human nature is flawed. Exchange without authority would degenerate into force and fraud. Without politics it would be Hobbes all the way to the knacker's yard.

Political economy is the synthetic subject that links together the national product and the rules of the game. Situated in the no-man's-land between opulence and defence, its focus is on 'the reciprocal and dynamic interaction...of the pursuit of wealth and the pursuit of power' (Gilpin, 1975: 25). It is a doubly dismal winterscape where neither the economic nor the political counters will ever be sufficient to satisfy all of the wants of all of the players. 
Gilpin defines political economy as the study of two parts forever compounded into a single whole: 'In the real world wealth and power are ultimately joined' (1975: 43). The key word is the and. Agriculture, industry and services generate the resources that fund the protective and the productive state. The superstructure of authority supplies the laws, the law enforcement and the public goods which emancipate ordinary men and women to make the most of their potential. It is a circular flow of symbiosis and support in which the and is the word that does the work. Politics and economics are interdependent: 'Every economic system rests on a particular political order; its nature cannot be understood aside from politics' (Gilpin, 1975: 40-1). Economics and politics are two sides of a coin: 'Economic forces are in fact political forces... The science of economics presupposes a given political order, and cannot be profitably studied in isolation from politics' (Carr, 1981 [1939]: 116, 117). Political economy is the synthetic subject that restores the two halves to the whole.

Global political economy is the intellectual orientation that opens the economy and the state to the world. Neither international economics nor international relations, it is concerned with the mutually causative relationships between resources and rules in an integrated matrix where foreign commodities, foreign values, foreign languages and foreign people are crossing the borders. We are all parts one of another.

Thomas Friedman has used the evocative phrase 'the world is flat' (2007: 1) to describe the overlap, the complementarity, the convergence and the interdependence. Once upon a time the world was round. National economies and sovereign polities did what they did to meet the needs of their own people. Nowadays the world is flat. Goods and services are being produced in multinational supply chains. They are being traded world-wide in line with codes promulgated by supra-national quasi-states exercising some of the functions of a world government. Both exchange and authority are being swept along by external forces over which the nation state has only limited influence. Political economy is becoming international political economy. A synthetic and multidisciplinary subject, it has to look outwards for explanations that are the property of no single state.

It is a no-man's-land at home. It is a no-man's-land abroad. This book is set in the no-man's-land where markets are embedded in nations and nations are embedded in the globe.

Chapter 11, Money without borders, shows how superstate lenders, more in tune with search and automaticity than with detailed plans and micromanagement, impose tried-and-tested systems that will rescue sovereign borrowers from macroeconomic contagion. Chapter 10, International liquidity, examines the unique status of the American dollar in an open market that, despite Bretton Woods, has lost its gold standard but not yet agreed on a non-national replacement. 
Chapter 9, The multinational enterprise, shows how the transfer of capital and technology is bound up with the internal politics of the corporate hierarchy and the national objectives of the host country's political structure. Chapter 8, Development and trade, links the terms of trade to government-managed import substitution and to export-led growth where even in a market economy the state might be expected to prime the pump.

Chapter 7, The developing countries, explains that the factors of production are the ingredients in the cake of growth, but that the well-being a poor country can squeeze from its latent endowments is impacted by the infrastructure and vision that are the productive input of the state. Chapter 6, Regions and blocs, considers whether free trade agreements and regional understandings, transcending the liberals' self-stabilising pull of homeostatic gravity, may be diverting trade and not just creating it.

Chapter 5, Goods and services, situates absolute, comparative and competitive advantage in the context of the politically orchestrated reduction in tariffs and other barriers to the free trade in things, rights and information. Chapter 4, The hegemon, drawing its examples from Britain in the nineteenth century and the United States (US) after 1945, discusses the role of the superpower in defence and economics.

Chapter 3, The national interest, rejecting the black box of an unexplained aggregate, explores the impact of pressure groups, social classes, industrial alliances, political coalitions and self-seeking bureaucrats on the specification of a non-market collective purpose from which some will lose even as others gain. Chapter 2, Science and ideology, trawls through the belief-systems of liberalism, socialism and nationalism to explain the clusters of heuristics and preconceptions under which underinformed men and women, condemned by complexity and change to ignorance and uncertainty, are forced to seek a second-best shelter.

This chapter is about the global political economy. It is the shortest chapter in the book. That is the key. Economics, politics, political economy and the international space mean different things to different people. Different observers are attracted to different paradigms for the same reason that different dog-lovers are attracted to different dogs. Dogs are different. One size does not fit all.

Some observers, applying the formal, quantitative, positivist approach of physics and engineering to the social demi-sciences of economics and politics, will be attracted by the interest-based, calculatively rational orientation of the utilitarian market. They will use methodological individualism to factor explanations down to the unique atom making a unique choice once. They will derive knowledge about causal sequences from empirical observation and the number-crunching of slimmed-down hypotheses. 
Other observers will prefer a holistic world-view that extends to historical evolution, normative socialisation, philosophical schemata and the causative multiplier of ideas. They will make a value-laden assessment of the starts and finishes that are the unintended outcomes of economic transformation and negotiated rule-making. They will use their empathetic understanding to grasp the subjective meaning of social mores and cultural norms. Convinced that there is more to political economy than material affluence, they will venture into problem areas such as poverty, gender, race and the environment for which neither economics nor politics can fail-safe a one-size-fits-all.

Dogs are different. People are different. Without curiosity, without compromise, without an openness to civilised dialogue, economics would be the exchange of insults and politics the suppression of dissenting opinion. There is no alternative. There is no other way. 